\title{
STATISTICAL ANALYSIS OF CHOSEN ASPECTS OF THE SUBURBANIZATION PROCESS IN SZCZECIN IN 2006-2011
}

\author{
Sebastian Gnat, Ph.D \\ Department of Econometrics and Statistics \\ University of Szczecin \\ e-mail: sgnat@wneiz.pl
}

\author{
Marcin Bas, M.Sc. Eng. \\ ESTIT (www.estit.pl) \\ e-mail:m.bas@estit.pl
}

\begin{abstract}
Suburbanization is one of the processes of urban expansion which is inseparably linked with the real estate market. It takes place when residents of cities gradually leave their administrative limits in order to live in satellite communities. The article presents studies dealing with the demographic and market-related aspects of this phenomenon. The authors analyzed the dynamics of prices of undeveloped plots of land chosen due to their location in municipalities (gminas) located in the proximity of Szczecin. The analysis was supplemented with a survey of average plot sizes and the number of transactions concluded in subsequent years. The dynamics of population flow from the West Pomeranian capital to the urban-rural fringe were also investigated. The analyses resulted in the proposal of a synthetic measure illustrating the suburbanization dynamics which combines the market dimension (prices and the number of transactions) with the demographic dimension (population flow). The study covered the period of 2006-2011.
\end{abstract}

Keywords: suburbanization, real estate market analysis.

JEL Classification: R14, R32.

Citation: Gnat S., Bas M., (2013), "Statistical analysis of chosen aspects of suburbanisation process in Szczecin in 2006-2001", Real Estate Management and Valuation, vol. 21, no. 3, pp. 71-80.

DOI: $10.2478 /$ remav-2013-0028.

\section{Introduction}

One of the aspects of real estate market growth is a phenomenon called suburbanization. There are many definitions of this term that differ in details. Traditionally, suburbanization has been defined as the process of shifting urban land use forms outside the inner city to surrounding rural areas as well as the process of the functional consolidation of suburbanised areas with the inner city. According to another definition, suburbanization is the process of the decentralisation of urban areas resulting from the migration of people and businesses from the inner city to the suburbs (LISOWSKI, GROCHOWSKI 2008). Suburbanization is also described as the process of "the flow of urban functions over neighbouring areas" (КОКОТ 1995). To be more precise, it happens when city residents, especially the well-off ones, gradually out-migrate from the city administrative limits in order to settle down in the neighbouring areas. In Poland, however, suburbanization does not always mean the migration of wealthy residents. After some economic calculation, people often find that the cost of a flat in a big city is comparable to the price of an undeveloped plot in the vicinity of their city or in its suburbs plus 
the costs of building a new single-family house. It is often said that suburbanization is caused by (DYLEWSKI 2007):

- so called "urban civilization",

- the mobility of societies,

- the will to live outside the city,

- inefficient land use management in many gminas.

Suburbanization is a wide-spread process that has been observed both in developed and developing countries. In fact, it is seen in metropolitan areas and is regarded as one of their development phases. On the one hand, this process is treated by its participants as a remedy to all the disadvantages of city life, such as air pollution, crime, noise, the loosening of social bonds or busy roads. On the other hand, when the suburbanization process is viewed from a broader perspective, it is often seen as negative.

It is frequently indicated that "in the history of human settlement suburbanization usually had a spontaneous character because in principle it used to solve problems of some of the city residents (...) and, to a varying degree, of the inner city authorities that could not cope with, for example, degradation of the inner city districts or could not afford the construction of new housing and social infrastructure" (CIOK, MiGOŃ, 2010, p. 94). In reference literature, we can find even more critical opinions that "Suburbanization and the urban sprawl are (...) one of the diseases of modern urban life" (MILCZYŃSKA-HAJDA, 2010). Nevertheless, the processes linked to the flow of the urban population to the urban-rural fringe have become a popular subject of study. Researchers analyze its causes (see: HARRIS 2004, MIESKOWSKI, MILLS 1993) and economic effects (BRUECKNER, IRWIN 1983 and others), as well as its environmental impact (Kahn 2000). Urban sprawl is also observed in Asia (see: FAHUI WANG, YIXING ZHOU 1999). Suburbanization in Polish cities, including Szczecin, has been the subject of study for over a decade and its effects are analyzed on many levels (see: GNAT 2004, 2012, DOSZYŃ 2006, KОKOT AND KIEPAS-КОKOT 2011, etc.).

From the real estate market and its participants' point of view, there are many reasons behind suburbanization (e.g., ineffective land use policies or their absence in gminas) and the phenomenon brings about many changes, such as: increased market attractiveness of certain suburban areas the attributes of which (e.g., easy access to the inner city or a nice landscape) appeal to prospective residents. Increased attractiveness is understood here as the rise in transaction prices of $1 \mathrm{~m}^{2}$, a larger number of transactions or more people choosing to settle down in the given area.

The aim of this study is to assess the scale of suburbanization in the Szczecin area expressed by the prices of undeveloped plots ${ }^{1}$, the number of such transactions and out-migration to the rural fringes of Szczecin. In order to prove the hypothesis that the migrating population uses the new areas for settlement, the author investigates the strength and direction of the relationship between the number of transactions and the migration of people from the neighboring gminas. In the final part of the paper, the author presents a synthetic measure called the market suburbanization measure. This measure combines the aspects of changing prices, the changing number of transactions on the real estate market and changes in the volume of migration to the gminas located in the outskirts of Szczecin. Monitoring this measure will help to follow the changes in the market aspects of suburbanization as well as compare the changing or relatively stable buyers' preferences in the individual gminas, which not only makes for interesting research material but may also contribute to an increased number of investment decisions.

The study deals with gminas located along the city limits of Szczecin, on the left bank of the Odra River, i.e.: Dobra (Szczecińska), Kołbaskowo and Police². These gminas are a part of the Szczecin metropolitan area (see Fig. 1). The authors have chosen these gminas because, being so close to the city center, they are the most affected by the suburbanization process and their local real estate market is most determined by the population flow from the city. Brief characteristics of the analyzed gminas in the Szczecin metropolitan area can be found below (see: КОКОт and KIEPAS-КОКОТ 2011).

Kołbaskowo is a rural gmina within the borders of the Poviat of Police. Despite the outward expansion of the city, it has managed to maintain its agricultural character. For many years, the policy

\footnotetext{
1 Because there was no set agenda for the plots in the Local Area Development Plan, the author decided to take into consideration traded plots of less than 3,000 square meters in area as ones with an optimum size for housing developments.

2 In the case of Police, the demographic aspects of the study include only the rural areas.
} 
of the local authorities has been focused on preventing scattered residential development. Instead, urban expansion has been directed to chosen areas and multi-family residential developments have been encouraged.

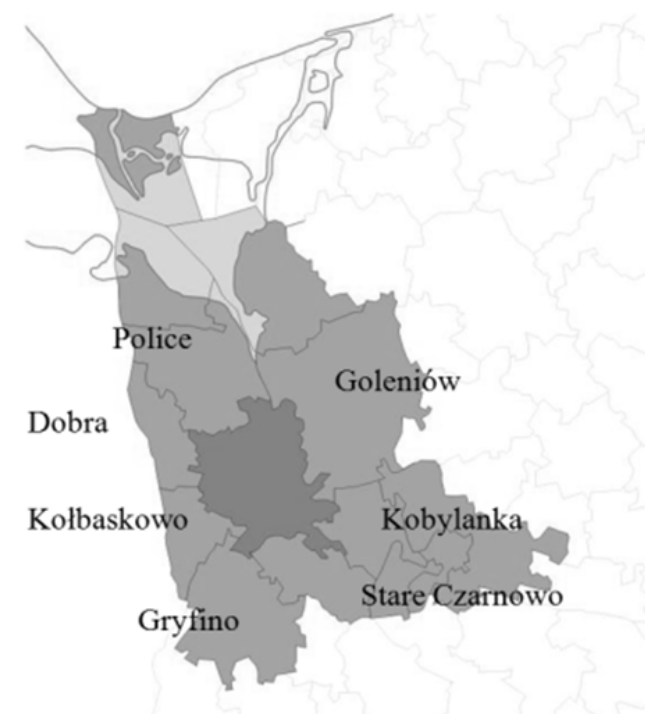

Fig. 1. Szczecin metropolitan area, Source: Swianiewicz P., Klimska U. 2005.

Dobra is also a rural gmina located in the Poviat of Police. Its traditional farming character is being replaced by residential functions, mainly in the form of scattered single-family houses, which has turned it into a typical suburban bedroom community.

Police is a rural-urban gmina situated to the north-west of Szczecin. The town is also the capital of the poviat. The largest employer in the town is the Police Chemical Plant which is surrounded by investment areas of the Police Industrial Park. The villages of Pilchowo and Tanowo are the most popular places to which the residents of Szczecin migrate.

The study covers the period of 2006-2011, i.e., from the time of the boom in the real estate market to the first years after the world financial crisis. For the purpose of the study, the market of undeveloped plots was divided into sub-segments. In each gmina, the authors found two areas (Area I and Area II) which were particularly attractive from the perspective of suburbanization. Areas I included land that offered the most favorable conditions for suburbanization, while Areas II, though located just outside the city limits, did not have as attractive of a location and the commuting system was worse than that of Area I. The individual variables under study (mean plot prices and sizes) in both Areas were compared with the levels observed in the gminas as a whole.

\section{The suburbanization of Szczecin}

When analyzing the suburbanization process in Szczecin, the authors focused on its demographic and market manifestation. In terms of demography, they examined the scale of the residents' migration from Szczecin to the surrounding gminas. The study was conducted using intensity indices of migration to rural areas per 1,000 people 3 (GNAT 2004). These measures are referred to as demographic suburbanization indices $(D S I)$. One of them measures the scale of migration from

\footnotetext{
3 The reason for choosing such an index is the good availability of statistical data as well as the assumption that residents who decide to leave the city and move out to rural areas generally choose a location in the close vicinity of the city they have left. The author assumes that the datum concerning urban-rural migration refers to the migration areas close to a large city. This is a simplification which is, obviously, not well-grounded, but the presumption was made following the survey of local real estate agents. City residents who decide to migrate to villages (according to the Polish Central Statistical Office) also include those who choose more distant locations. The assumption that the whole migrating population prefers to stay on the edge of a city distorts migration indices. Yet, the author believes that the distortion is not significant enough to affect the importance of the proposed indices for the process of drawing conclusions about the demographic aspects of suburbanization. What is more, the author compared the general number of residents leaving Szczecin for rural areas with the number of people migrating from Szczecin to its rural fringes. The relative mean difference was $4.5 \%$.
} 
Szczecin $\left(D S I_{u}\right)$, while the second - the scale of migration from Szczecin to each of the analyzed rural gminas $\left(D S I_{r}\right)$.

$$
D S I_{u}=\frac{m_{r}}{l_{u}} \cdot 1000
$$

where:

$D S I_{u}$ - the urban demographic suburbanization index,

$m_{r}$ - the number of people emigrating from the city to rural areas,

$l_{u}$ - the population of the city.

$$
D S I_{r}=\frac{m_{u}}{l_{r}} \cdot 1000
$$

where:

$D S I_{r}$ - the rural demographic suburbanization index,"

$m_{u}$ - the number of people emigrating from the city to a rural gmina,

$l_{r}$ - the population of a gmina.

Szczecin has been experiencing suburbanization for more than a dozen years and the dynamics of the process are positive. Figure 2 shows the changes of the DSI $I_{u}$ index in Szczecin in 1995-2011.

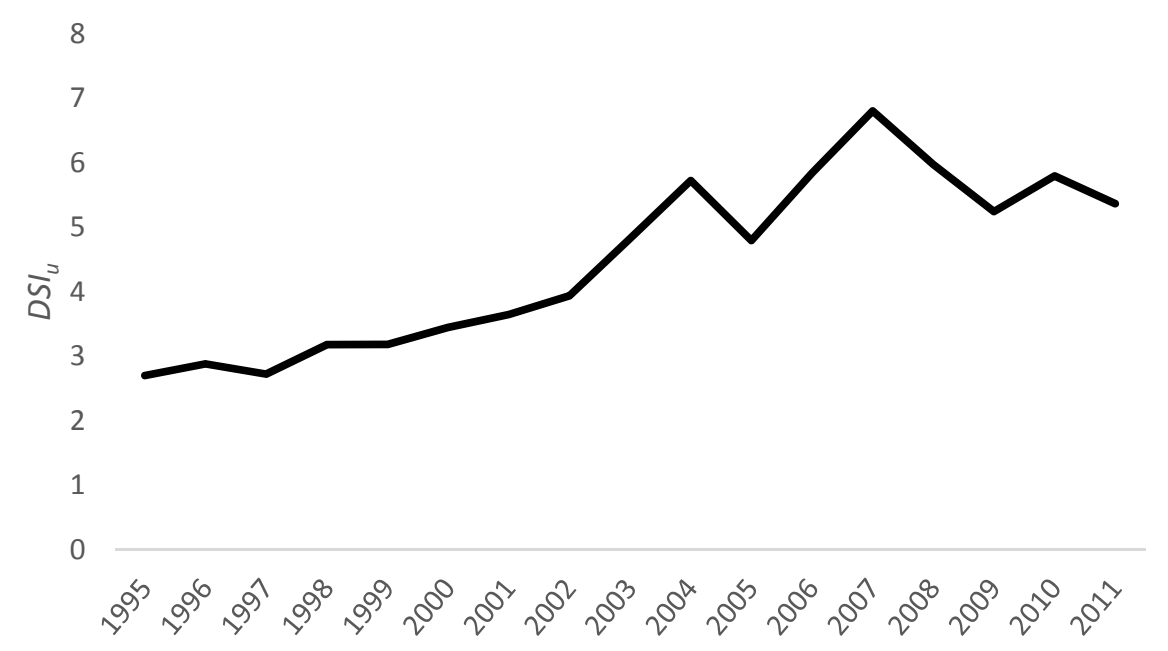

Fig. 2. Changes in the DSI index in Szczecin in 1995-2011, Source: own study on the basis of the Local Data Bank.

In the analyzed period, the Gminas of Dobra, Kołbaskowo and Police (rural area) saw the inflow of two thirds of the population that had moved out of Szczecin. Figure 3 shows the changes of the DSIr index in the surveyed gminas in 1995-2011. Gminas, including the ones around Szczecin, are usually characterized by small populations and present hardly any statistical regularities. However, despite this limitation, it is obvious that there is a relation between the increased intensity of the outward migration from Szczecin to rural areas and the population inflow from urban areas to the analyzed rural ones.

The size of the real estate market and the relatively small population makes the statistical study difficult to conduct. Other authors in their studies of the real estate market pointed to deficits or the absence of statistical regularities which reveal themselves only in large data sets (Foryś 2011). In Police and Dobra, the general tendency of the $D S I_{r}$ index has been found to be increasing. However, this tendency changed after 2008. In Kołbaskowo Gmina, no upward tendency was observed. This is associated with the local government's priority policy to maintain the rural character of the area. Nevertheless, in the time of the boom on the real estate market the inflow of new residents grew from year to year even in this gmina. 


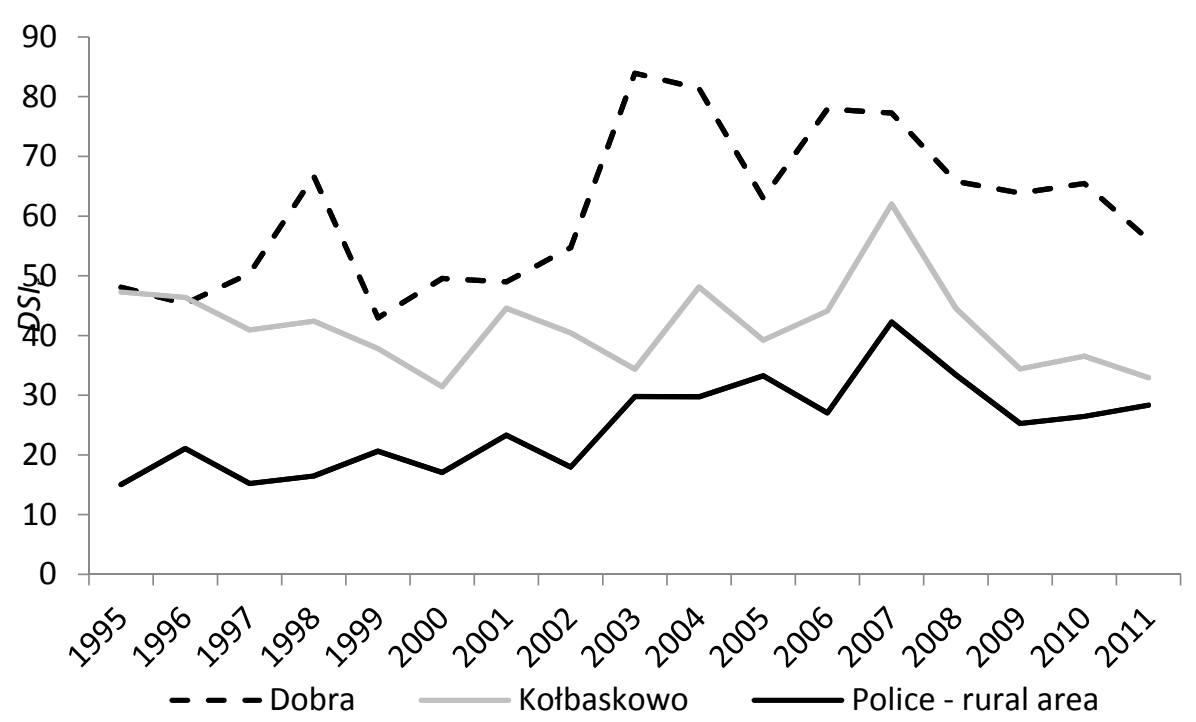

Fig. 3. The $D S I_{r}$ index in Dobra, Kołbaskowo and Police (rural areas) in 1995-2011, Source: see above.

\section{Statistical analysis of the market of undeveloped plots in the analyzed gminas}

The analysis of the real estate market in the context of the ongoing suburbanization process in Szczecin covered such factors as the median of transaction prices of 1 square meter of undeveloped plots, the number of concluded transactions and the median of the traded plot sizes. The author decided to use a measure of location such as the median due to its resistance to extreme values, which is particularly important in the case of small sets, where one object on the real estate market can disturb the existing regularity. The study covered the period of 2006-2011.

As it has already been mentioned, two areas, the specific value of which had made them particularly attractive for suburbanization, were distinguished in each gmina. The data from those areas was compared with data concerning the gminas in general (excluding the city of Police in the Gmina of Police). In the Gmina of Dobra, Area I consisted of such districts as: Bezrzecze, Dobra, Mierzyn 1, 2 and 3, Skarbimierzyce and Wołczkowo. Area II covered the districts of Buk, Dołuje, Grzepnica, Kościno, Łęgi, Pilchowo, Redlica, Rzędziny, Sławoszewo, Stolec and Wąwelnica. In the Gmina of Kołbaskowo, Area I consisted of the districts of Kurów, Ostoja, Przecław, Rajkowo, Siadło Dolne, Siadło Górne, Ustowo and Warzymice, while Area II encompassed Barnisław, Będargowo, Bobolin, Kamieniec, Karwowo, Kołbaskowo, Moczyły, Pargowo, Przylep, Smolęcin and Stobno. In the rural part of the Gmina of Police, Area I covered the districts of Pilchowo, Przęsocin, Siedlice, Tanowo and Trzeszczyn. Area II covered Dębostrów, Drogoradz, Mścięcino, Niekłończyca, Przylep, Tatynia, Trzebież (all the districts), Uniemyśl and Zalesie. The specified Areas have been shown in Fig. 4.

Figure 5 presents the changes in the median transaction price of 1 square meter of undeveloped plots in the Gminas of Dobra, Kołbaskowo and Police (rural area) in 2006-2011, broken down into Area I and Area II, as well as in the gminas in general. Two conclusions can be drawn from the presented data. Firstly, the prices in the first area of suburbanization were higher than in the second, which means that the market "appraisal" of the advantages of the former justified the division into two Areas performed by the author. The second fact revealed by the study was that the price-related reaction of local markets to financial turbulence in the world can be different. The prices did not slump locally after the world crisis. The lack of a strong price-related response to the world crisis on the real estate market in Szczecin has already been discussed in literature (see: PĘCHORZEWSKI 2011). The most significant fall of prices was observed in 2009, when the opinions and forecasts concerning the real estate market were the most pessimistic. On the analyzed markets, the prices in Areas I decreased simultaneously in 2011. The most stable situation was observed in the Gmina of Dobra, which held leading positions in the group of all the gminas surrounding Szczecin in terms of prices, the number of transactions and the volume of population inflow (see: GNAT 2012). 


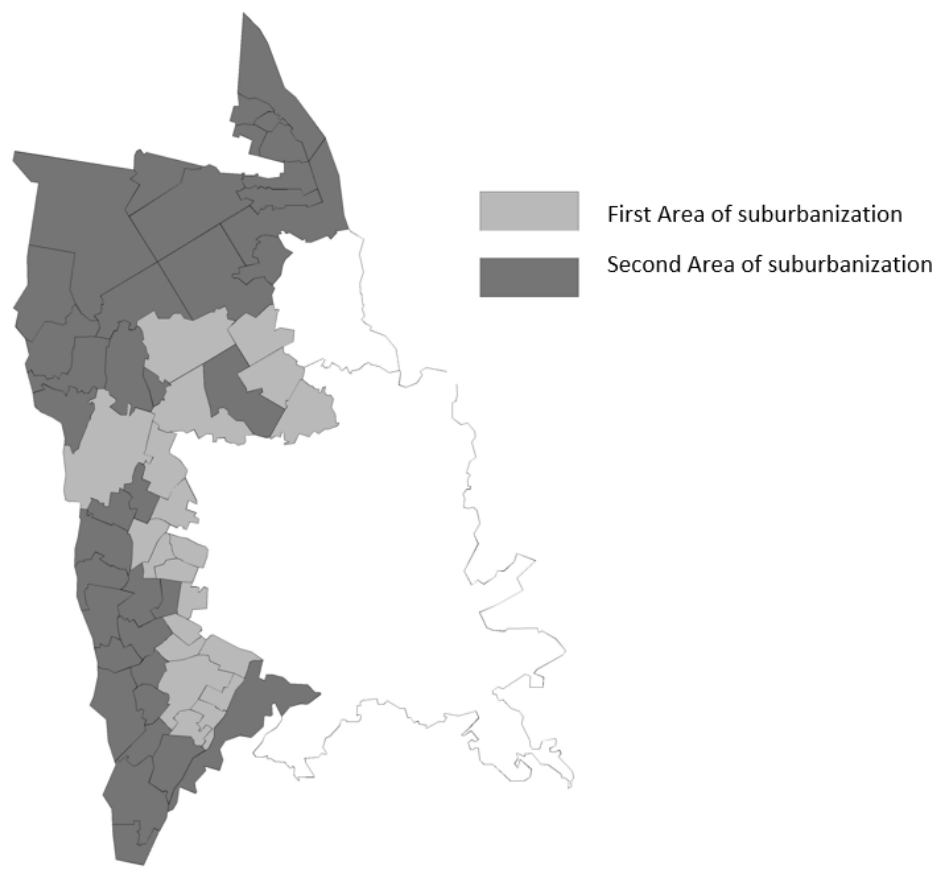

Fig. 4. Areas I and II in the Gminas of Dobra, Kołbaskowo and Police, Source: own study.
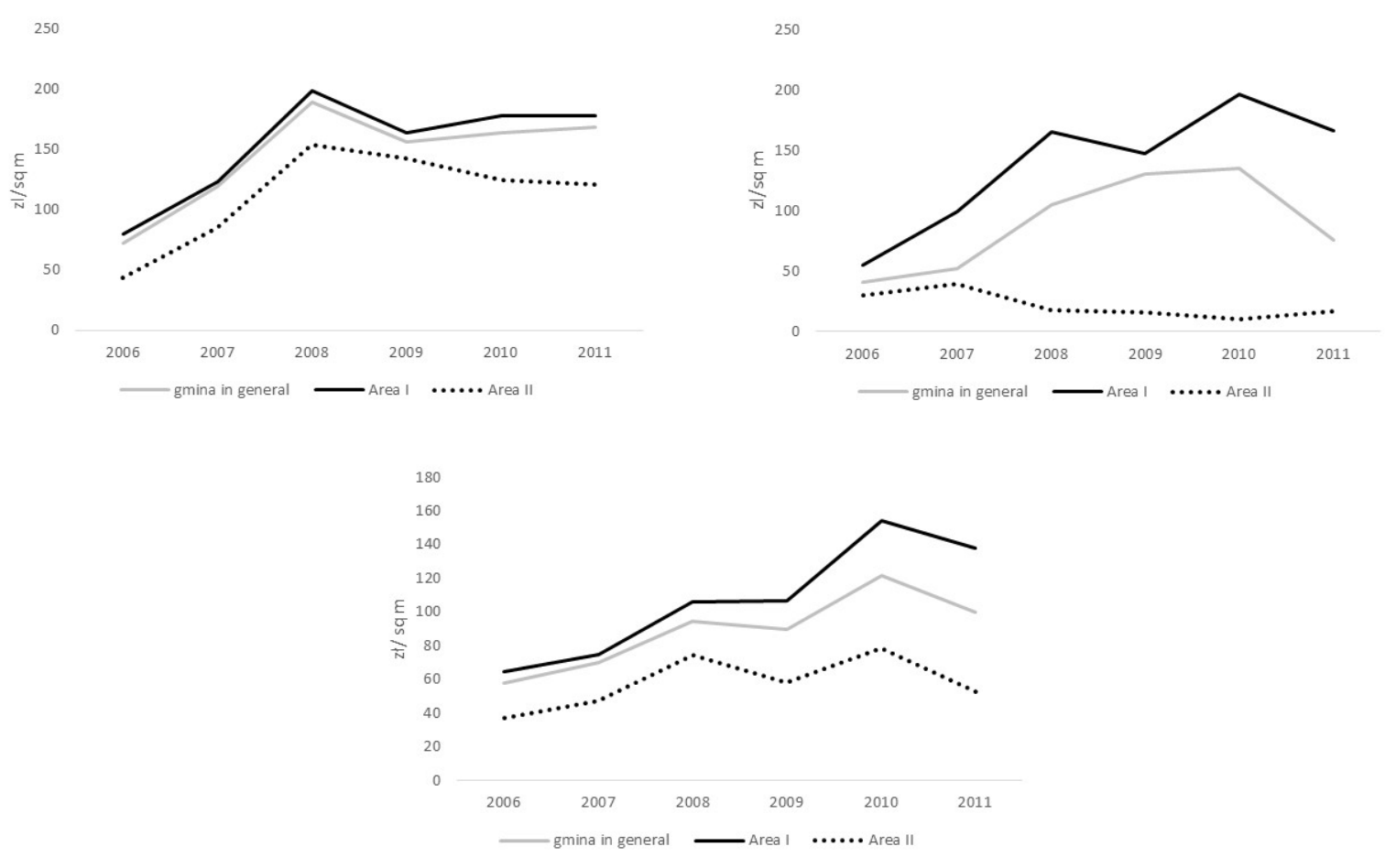

Fig. 5. The median of transaction prices of 1 square meter of undeveloped plots in the Gminas of Dobra, Kołbaskowo and Police (rural area) in 2006-2011, Source: own study.

When analyzing the number of transactions in the areas specified in the study, the author observed that in the gminas whose local authorities did not discourage housing development, much more transactions were concluded in Areas I of suburbanization (see Fig. 6). The most significant differences were seen at the time of the boom, i.e., in 2006-2007. The above relationship did not take place in the Gmina of Kołbaskowo, which once again confirms that this particular gmina differs from the Gmina of Dobra and the rural part of the Gmina of Police. 


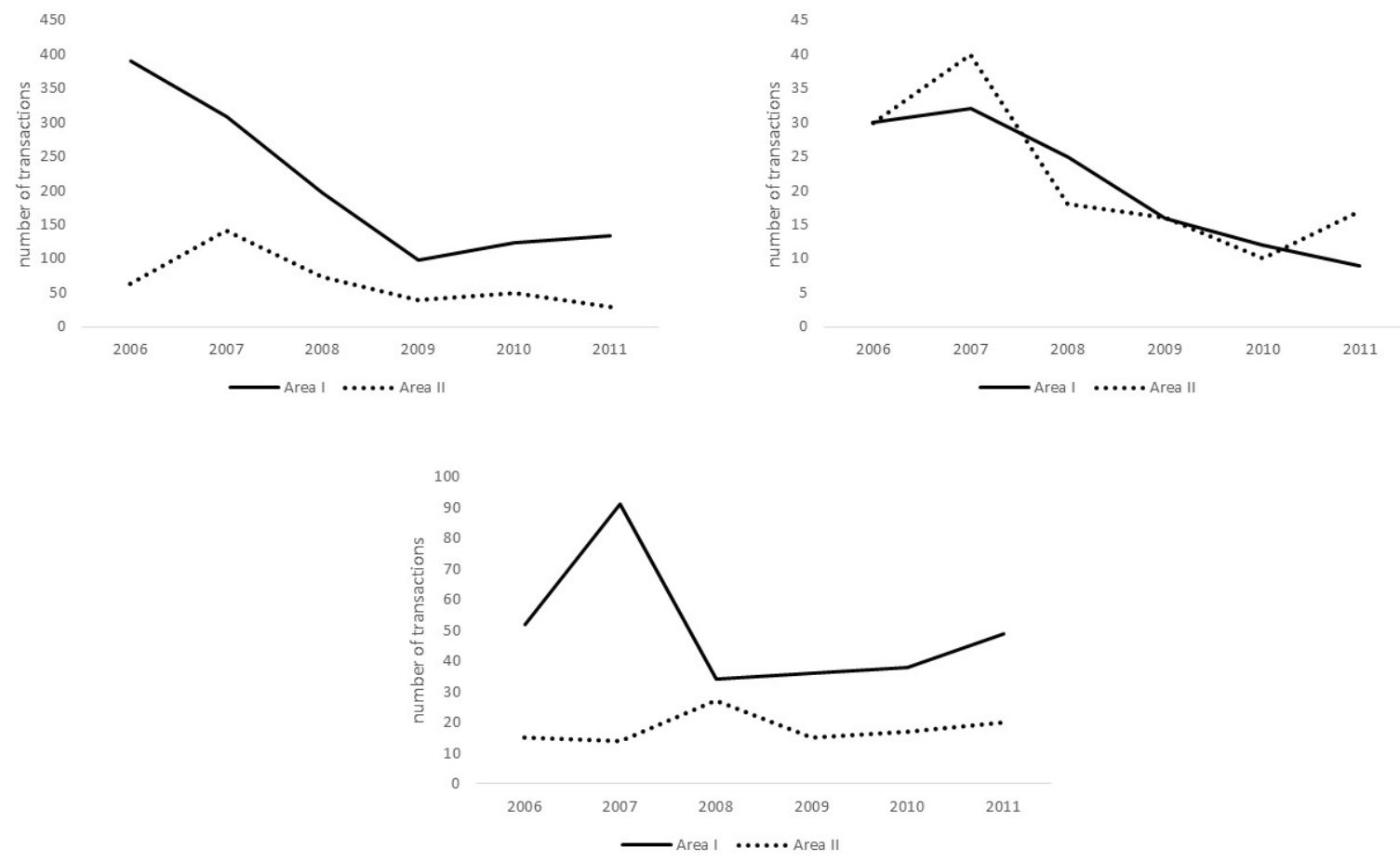

Fig. 6. The number of transactions concerning undeveloped plots in the Gminas of Dobra, Kołbaskowo and Police (its rural part) in 2006-2011, Source: own study.

In order to test if the population inflow to the suburban gminas located on the left bank of the Odra River (as presented in Fig. 3) is associated with the progressing suburbanization of Szczecin, the author examined the correlation coefficients between the number of transactions in Areas I, which are most attractive to the migrating residents of Szczecin, and the $D S I_{r}$ indices. The author accounted for a one-year delay of the transactions in relation to the population inflow. The coefficients have been presented in Table 1.

Table 1

Pearson correlation coefficient between the number of transactions in Areas I and the delayed by a year $D S I_{r}$ indices in the Gminas of Dobra, Kołbaskowo and Police (rural part)

\begin{tabular}{ccc}
\hline Dobra & Kołbaskowo & Police \\
\hline 0.79 & 0.68 & 0.46 \\
\hline \multicolumn{3}{c}{ Source: own study. }
\end{tabular}

In all the analyzed gminas, the relationship between the number of transactions on the plot market and the intensity of the migration from Szczecin expressed by means of the index was positive and moderately strong. This means that land located within Areas I turned out to be a destination for people migrating from Szczecin, which confirms the observation that the process of suburbanization is in progress - a significant share of those residents who decide to leave the city choose new, undeveloped areas.

The last stage of the presented statistical analysis of suburbanization in Szczecin was the comparison of the average sizes of traded plots. Figure 7 shows the changes in the medians of plot sizes in the period of 2006-2011 in the discussed gminas. The collected material displays certain regularity. Generally speaking, the plot size medians in Areas II were slightly larger than in Areas I. This means that in areas where the undeveloped plot prices are higher, the sizes of the traded plots are a little smaller. Taking into consideration all the examined gminas, the differences between the size medians in Areas I and II reach 2\%. Again, it is worth mentioning that in such small areas as parts of gminas, statistical measures often consists of single abnormal data sets that can be misleading. 
Nevertheless, plot sizes in Areas I were generally smaller, though the difference wasn't significant. A conclusion can be drawn that the buyers of undeveloped plots situated in Areas I were willing to pay more for property of higher value in comparison to that available in Areas II. Apparently, the financial aspect did not prevent buyers from purchasing plots in the most attractive locations.
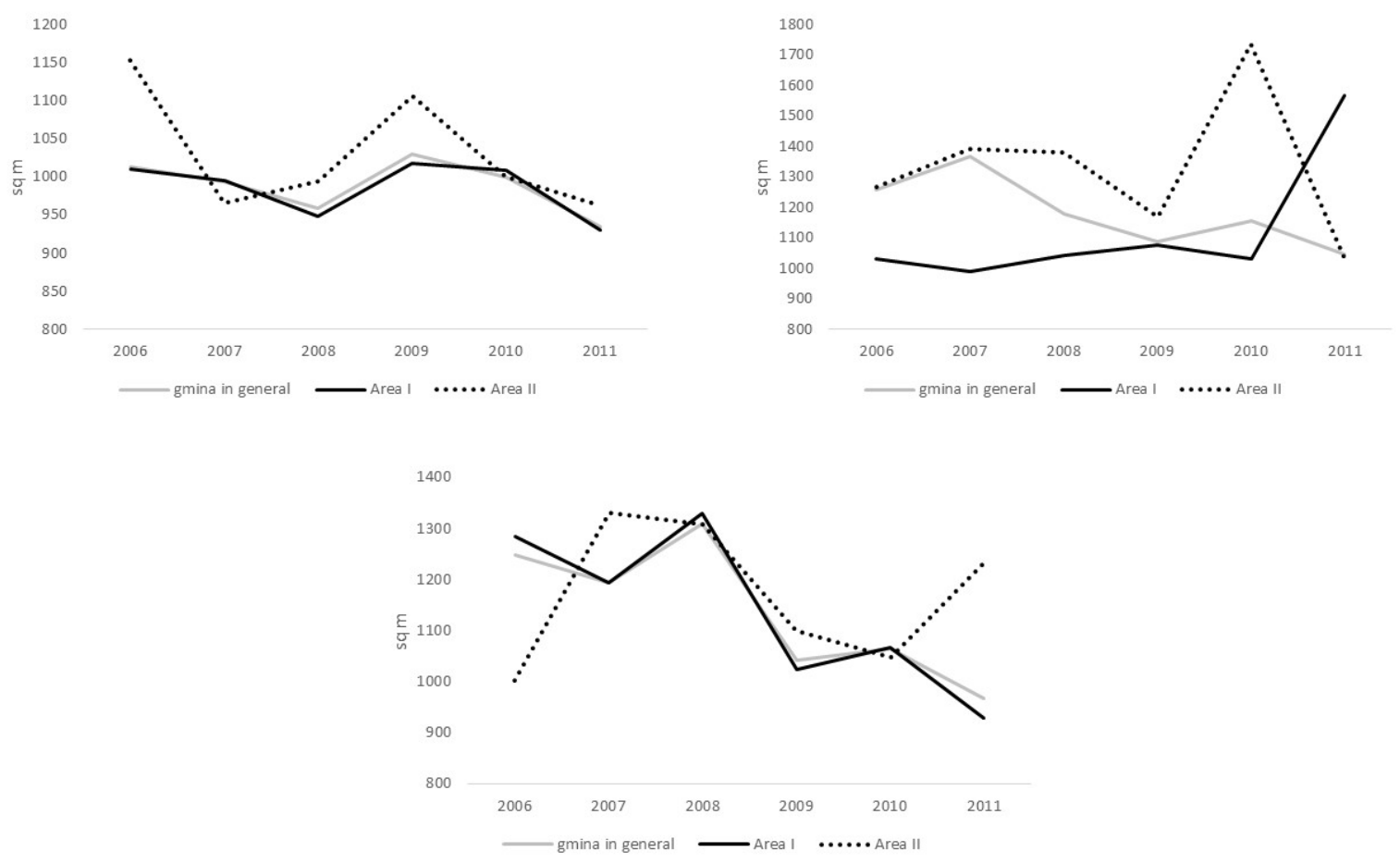

Fig. 7. The median size of undeveloped plots traded in the Gminas of Dobra, Kołbaskowo and Police (rural part) in 2006-2011, Source: own study.

\section{Market Suburbanization Index (MSI)}

The author's attempt to approach the process of suburbanization in Szczecin has resulted in the construction of a synthetic measure being the geometrical mean of: the index numbers of the price median of 1 square meter of undeveloped plots, the number of transactions and the $D W S_{w}$ index in the individual gminas. The application of the geometrical mean of index numbers as the measure of trends had been recommended in several earlier studies (see: Hozer 2008, Hozer and Rozkrut 2009, or Gdakowicz 2010).

$$
M S I_{t}=\sqrt[3]{I C_{t-1 / 0} \cdot I T_{t-1 / 0} \cdot D S I_{t / 0}}
$$

where:

$M S I$ - the market suburbanization index in the year $t$,

$I C_{t-1 / 0}$ - the index number of the median of transaction prices of 1 square meter of undeveloped plots in the year $t-1$ in a given gmina,

$I T_{t-1 / 0}$ - the index number of the number of traded undeveloped plots in the year $t-1$ in a given gmina, $D S I_{t / 0}$ - the index number of the demographic suburbanization index in the year $t$ in a given gmina ${ }^{4}$.

Due to the fact that the subjects of the analysis are undeveloped plots and the population inflow to a given gmina, the construction of the MSI should include the investment process, the effect of which is a residential building. In addition, it is difficult to estimate how long the investment in each gmina is going to take; that is why the author decided to use data concerning transaction prices and numbers that was collected one year later than data concerning migration intensity.

Owing to the limited availability of information, the MSIs were calculated for the years 2008-2011. Figure 8 shows the changes in the Market Suburbanization Index in the analyzed gminas.

${ }^{4} \mathrm{~A}$ base year for the demographic suburbanization index is the year subsequent to the year chosen for the price median and transaction number. 


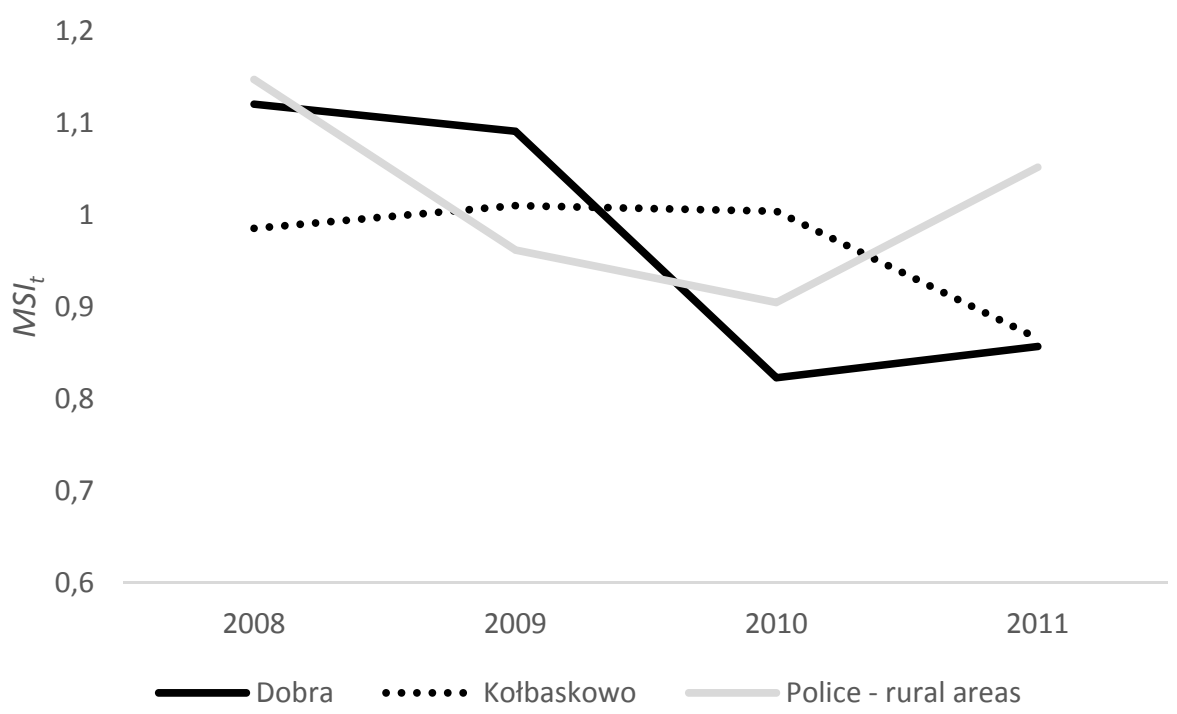

Fig. 8. Market Suburbanization Index in Dobra, Kołbaskowo and Police (rural part) in 2008-2011, Source: own study.

The MSI should be interpreted as follows: values below 1 indicate a market situation worse than in the base year of the study (i.e., in 2007); values larger than 1 mean that the situation is better. In the context of suburbanization, the Gmina of Dobra and the rural parts of the Gmina of Police saw a downturn in the period of 2008-2010, i.e., at a time when markets were reacting to the speculation bubble burst and banks tightened their credit policies. In 2011, a slight upward trend was observed. An analysis of the year to come will show if the change of trends is of a permanent nature. In 2011, Police was the only gmina which experienced a better market than in the base year. It is worth emphasizing once again that surveys of local markets are burdened with risk caused by single factors that can disturb the existing regularity. Yet, taking into consideration the general information about the situation on the real estate market, the MSI readings seem to be accurate. Kołbaskowo was the only gmina where the market situation did not get worse, which is not surprising in view of the local government's policy that resulted in a much smaller number of transactions than in the other two gminas where the suburbanization process has taken a different course.

\section{Conclusion}

Suburbanization is a process which, despite the negative opinion of urbanists, is an essential phase of the development of big cities. There are many causes as to why it occurs and its very presence is worthy of attention and scientific studies. Szczecin is one of the largest Polish cities and thus, it is also experiencing the sprawl of its functions to the outside of its administrative limits. Because of its geographical position and set of attributes, including easy commuting and local government policies in the neighboring gminas, suburbanization in Szczecin is directed to the west and north of the city. In this study, the authors analyzed the changes in the transaction prices of undeveloped plots, the number of transactions and the size of the traded plots. Additionally, the study included the aspect of the population flow from Szczecin to the neighboring municipalities (Gminas) of Dobra, Kołbaskowo and the rural parts of the Gmina of Police. It was observed that, in the course of the last several years, the process of migration from the West Pomeranian capital had continued. When analyzing the market of undeveloped land in terms of suburbanization, the authors distinguished two areas having specific suburbanization potential, i.e., accessible for commuters from and to the inner city, in each gmina. The study showed that in Areas I (with the highest potential), the price medians were higher by up to several dozen percent than in other parts of the gminas. What is more, the number of transactions in those areas was higher as well. On the other hand, the size medians were slightly lower than in other areas, which means that the attractive attributes of land properties in Areas I were reflected in the mean price levels. Potential buyers were ready to accept higher final transaction prices than in other parts of the gminas and the number of plots they purchased significantly affected the entire real estate markets in those gminas. The above regularities concerned mainly the Gminas of 
Dobra and Police, where local authorities did not discourage new settlement processes by means of administrative tools.

The ongoing suburbanization processes manifest themselves in various ways. Therefore, the authors propose a synthetic measure which can give a general picture of changes on the real estate markets where suburbanization is in progress. The proposed measure is flexible enough so that new data can be added when more quantitative aspects of the urbanization process are distinguished in order to describe the suburbanization in greater detail.

\section{Bibliography}

BRUECKNER J, IRWIN E., 1983, The economics of urban sprawl: Theory and evidence on spatial sizes of cities, Review of economics and statistics, no. 65, 479-482.

DoszYŃ M., 2006, Wptyw procesu suburbanizacji na sytuacje w mieszkalnictwie w gminach wokót Szczecina w latach 1996-2003, [w:] Polityka mieszkaniowa miasta Szczecina - zasoby mieszkaniowe w Szczecinie jako element rynku nieruchomości, Instytut Analiz Diagnoz i Prognoz Gospodarczych, Szczecin.

DYLEWSKI R., 2007, Żywiołowa suburbanizacja w świetle raportu komisji europejskiej i wnioski dla Polski, Człowiek i Środowisko, No. 1-2.

FAHUI WANG, YIXING ZHOU, 1999, Modeling Urban Population Densiies in Beijing 1982-90: Subrubanisation and its Causes, Urban Studies, Vol. 36, No. 2, 271-287.

FORYŚ I., 2011, Społeczno-gospodarcze determinanty rozwoju rynku mieszkaniowego w Polsce. Ujęcie ilościowe, Rozprawy i Studia T. (DCCCLXVII) 793, Uniwersytet Szczeciński, Szczecin.

GDAKOWICZ A., 2010, Badanie koniunktury na rynku lokali mieszkalnych w Szczecinie 1997-2006, Studia i Prace WNEiZ nr 20, Uniwersytet Szczeciński, Szczecin.

GNat S., 2004, Analiza statystystyczna efektu suburbanizacji w Polsce w latach 1996-2003, Interdyscyplinarne Wykorzystanie Metod Ilościowych IV, Szczecin.

GNAT S., 2012, Suburbanizacja Szczecina i jej demograficzne efekty w latach 1995-2010, STUDIA I MATERIAŁY TOWARZYSTWA NAUKOWEGO NierUCHOMOŚCI, OlSZTYN 2012, VOL. 20, No. 3.

HARRIS R., 2004, Creeping conformity: How Canada became suburban, University of Toronto Press. Toronto.

HOZER J., 2008, Prognozowanie rynku nieruchomości, Katedra Ekonometrii i Statystyki US, Instytut Analiz Diagnoz i Prognoz Gospodarczych w Szczecinie.

HOzer J. ROZKRUT D., 2009, Prognozowanie koniunktury gospodarczej regionu, Zeszyty Naukowe nr 561, Studia i Prace WNEiZ nr 15, Uniwersytet Szczeciński, Szczecin.

KAHN M.E., 2000, The Environmental Impact of Suburbanization, Journal of Policy Analysis and Management, Vol.19, No. 4, 569-586.

КокОт S., 2006, Gospodarcze aspekty suburbanizacji Szczecina, [w:] Życie gospodarcze Szczecina (monografia), Uniwersytet Szczeciński, Szczecin.

КокОт S., KIEPAS-КОКОт А., 2011, Efekty suburbanizacji aglomeracji szczecińskiej, [w:] Wiadomości statystyczne nr 7-8, s. 67-84.

LisowsKi A., GROCHOWSKI M. 2003, Procesy suburbanizacji. Uwarunkowania, formy i konsekwencje [w:] Ekspertyzy do Koncepcji Przestrzennego Zagospodarowania Kraju 2008-2003, KPZK-Ministerstwo Rozwoju Regionalnego, T. 1, 217-280.

MieSKOWSKI, P., MiLls, E., 1993, The causes of metropolitan suburbanization. Journal of Economic Perspectives, Vol. 7, No. 3.

MILCZYŃSKA-HAJDA D., 2010, Miasto XXI wieku, PROBLEMY - SZANSE - NOWE STRATEGIE ROZWOJU, Wprowadzenie do tematu, Instytut Rozwoju Miast, Kraków.

Przekształcenia struktur regionalnych. Aspekty społeczne, ekonomiczne i przyrodnicze, S. Ciok, P. Migoń (red.), 2010, Instytut Geografii i Rozwoju Regionalnego.

PĘCHORZEWSKI D. (2011), Evolution of the local residential real estate markets in selected Polish cities against the various phases of the global financial crisis, Eindhoven University of Technology Netherlands 2011, [w:] ERES DigitalLibrary, No. 2011_100, Published by University of Technology (TU/e), Eindhoven.

SWIANIEWICZ P., KLIMSKA U., 2005. Społeczne i polityczne zróżnicowanie aglomeracji w Polsce - waniliowe centrum, mozaika przedmieść, [w:] Prace i Studia Geograficzne, Tom 35, Warszawa. 